\title{
Research and Development and Tax Incentives
}

Sabina Hodžić* *

Abstract:

In many countries, tax incentives are a popular means to achieve political, economic and social objectives. Their aim is to reach and accelerate certain activities of public interest. Furthermore, one of the objectives is to accelerate the development of a certain industry and influence the growth of research and investment in foreign capital. Innovation is the key element that helps a company achieve competitive advantage. Global competition is forced to offer unique products with added values on the market. Tax incentives for research and development are an important factor of innovation. This paper aims to present the importance of research and development, as well as the role of tax incentives. States should use their fiscal policy to stimulate investment in research and development through various forms of tax relief. The Republic of Croatia applies tax incentives for research and development, but to a significantly less extent than other European Union countries.

Keywords: tax incentives, research and development, fiscal policy, direct measures

JEL: H25

DOI: $10.2478 / v 10033-012-0014-6$

\section{Introduction}

Since its aim is to achieve greater competitiveness than that of the United States of America and South Korea, the field of research and development is growing rapidly in the European Union. Many member states use fiscal incentives to invest in research and development. These represent a new means of investment in researchdevelopment activities in less developed countries. Globalization and new technologies have led the economy of the 21st century on to new challenges. Companies that perform their activities within the European Union must manage innovation activity in a high-quality and successful way. Successful management seeks educated staff and the fiscal incentives of the state. New system approaches and knowledge related to the innovation process encourage increased competitiveness. Research and development are one of the most significant processes of innovation. Innovation is a new and improved product or service presented on the market. A common characteristic of all innovation is that it must be implemented on the market. Market results show the profitability of a new product or service on the market. Innovation activities depend on the type and characteristic of a company introducing a new product or service. In most industrial companies in the European Union member states there are special departments for innovation activities. Several types of projects aiming to stimulate joint projects for research and development have been developed within the European Union. The European Commission has published the Horizon 2020 strategy, stating that investment in research and development should be increased to up to 3\% of GDP. Horizon 2020 emphasizes the importance of international cooperation in science, technology and innovation. Research and innovation are

\footnotetext{
* Sabina Hodžić

Faculty of Tourism and Hospitality Management, Opatija, Croatia

E-mail: sabinah@fthm.hr
} 
at the centre of this strategy. The strategy supports three important areas - the EU's position as a world leader in science, making Europe a more attractive location to invest in research and innovation and social challenges such as health, demographic change and well-being, food security, secure, clean and efficient energy, smart, green and integrated transport, climate action and inclusive, innovative and secure societies The European Union member states use fiscal policy to encourage research and development in order to achieve objectives in growth, productivity and competitiveness. Higher investments in research and development bring a more important business position and competitiveness to companies and add to the higher economic growth of a country.

\section{Literature Review}

Research and development expenditures have long been an important concern for innovation analysts, who have used them as a proxy for innovation inputs and as a determinant of productivity growth (Moncada-PaternoCastello, P. et al. 2010, p. 523). Governments try to reallocate or attract domestic and foreign capital using tax incentives that give more favourable tax treatment to certain economic activities (Klemm and Van Parys 2012, p. 394). The higher economic growth of a company demands more developed research-development cooperation between institutions. In addition to the positive sides of cooperation, there are a few negative ones as well. First, research and development cooperatives can collectively decide to cut research and development expenses if negative pecuniary externalities prevail. Second, an agreement to cooperate in research and development could facilitate collusion in other stages of the production process, a harmful reduction in competition which undoubtedly leads to a loss in net total surplus. Third, research and development cooperatives can act as s barrier to entry as they can, as a consortium of firms, set standards for future application (Hinloopen 2001, p. 314).

Firms need to complement their internal resources and capabilities with imported ideas from outside, interacting with a wide range of actors inside the innovation system (Sanchez-Gonzales and Herrera 2010, p. 338). According to this model, the advantages that firms obtain from internal research and development expenditures have decreased due to different factors, such as the increased mobility and availability of knowledge workers. It also emphasizes the interactive character of the innovation process, suggesting that firms need not and indeed should not rely exclusively on their own research and development (Sanchez-Gonzales and Herrera 2010, p. 338). Research and development activities must be tightly connected to national industry. Science and technology are the key components in the creation of a foundation for innovation, productivity and economic growth. The tax treatment of R\&D is becoming more lenient and it is likely that countries will increasingly turn to the tax system and away from direct grants (Hall and Van Reenen 2000).

\section{Importance of Tax Incentives for Research and Development}

A large number of the European Union member states, as well as future members, offer companies tax incentives for research and development within their fiscal policies. Research and development and innovation are considered key for the productivity and profitability of a company. Without a good and innovative product a company won't be able to achieve its business plan. To encourage this activity, many countries produce different types of tax incentives for research and development. Various types lead to differences between incentives among the member states, and thus to significant discrepancies.

The paramount importance of tax incentives for research and development depends on the economic policy of a state. A state that encourages greater economic growth uses more resources. Resources for the stimulation of research and development include the cooperation of research centres and the private sector, and direct financing from budget and tax incentives. Using tax incentives for research and development, the state controls the strategic direction of a company and its objectives. Fiscal measures offer markets an opportunity to determine the degree and category of investment. Tax incentives can be especially important for the stimulation of small and medium-sized companies. Small and medium-sized companies could thus gain a greater opportunity to accelerate their growth and competitiveness on the market. The continuous and longlasting survival of a company is achieved by creating new products and services, as well as added values. The new results of innovation, research and development show the successful development of companies and their competitiveness on the market. Research and 
development should be a more continuous process and an attempt to cover a part of the costs of current earnings (Batty 1976).

Many countries have introduced tax incentives for research and development in the past two decades. Most OECD countries nowadays apply a combination of tax incentives and direct subventions for research and development. The European Commission has focused more on tax incentives for research and development than in previous years. By doing so, it is trying to increase the efficiency and coherence of tax incentives for research and development. More developed economies use both direct and indirect incentives for research and development.

The contribution of research and development depends on the growth of productivity, economic efficiency and achieving social justice. Different national factors determine countries' preferences with regard to tax incentives, subventions, preferential rights or other instruments to encourage research investments. The choice of tax incentives for research and development depends on the following (Hutschenreiter 2002):

1. Degree of innovation;

2. Perceived market irregularities in research and development;

3. Industrial structure;

4. Company's size; and

5. Nature of tax system within company and respective country.

The efficiency of the tax incentives for research and development depends on the types of tax measures associated with the political objectives of a country. Member states encourage investment in business research and development because research and development has an important role in long-run economic growth. Furthermore, in times of crisis it maintains jobs, encourages national competitiveness and produces public goods. Today more than 20 OECD governments provide fiscal incentives for research and development, up from 12 in 1995 and 18 in 2004.

\subsection{Types of Research and Development}

In the European Union, as well as in the Republic of Croatia, there are several definitions and types of research and development that are being applied. The types of research and development include (Frascati Manual 2002):
1. Basic research -theoretical or experimental work carried out primarily to acquire new knowledge on the basics of occurrences and facts without concrete practical application.

2. Applied research -theoretical or experimental work performed to acquire new knowledge, primarily focused on achieving practical objectives.

3. Developmental research - work based on the results of scientific research and practical experience, focused on creating new materials, products and systems and the introduction of new processes, systems and roles or improvement of existing ones.

These types of research are conducted in several sector types: the business sector, government sector, non-profit sector and higher education sector.

According to Frascati (2002), several basic concepts related to research and development should be distinguished:

Gross Domestic Expenditures on Research \& Development (GERD) are the total internal expenditures for research and development in a country during the observed calendar year, comprising current and investment expenditures in gross amounts.

Business Enterprise Sector (BERD) comprises enterprises/companies and organizations whose main activity is the production of goods and services for the market at the economic price.

Government Sector (GOVERD) relates to institutions and other entities providing the community with such common services (except higher education) that otherwise, with market conditions, could not be provided, and they are a form of the community's economic and social policy.

Government budget appropriations or outlays (GBAORD) comprise all expenditures of the central government's budget.

Share of gross domestic expenditures for research and development show the expectations of a country for the creation of newer knowledge and technology, as well as simultaneous application of existing knowledge in the private and public sectors. Tax incentives for research and development usually occur in one of the following three forms (Kesner-Škreb 2001):

1. Tax deferrals - relief with respect to deferred tax payment;

2. Tax allowances - the possibility of tax allowance for the value added tax for the amount exceeding actual investments in research and development; 
3. Tax credits -amount deducted from tax liability, i.e. the possibility to reduce tax liability for a part of the expenditures for research and development.

Some countries, like Italy, the Netherlands and Spain, prefer tax credits over tax allowances. Tax policy has an important role in stimulating research and development as a response to high levels of risk associated with this category of investment (Tassey, 2007).

\subsection{Principles for the Creation of Tax Incentives for Research and Development}

When creating tax incentives for research and development, countries give priority to forms that include elements of simplicity, costs of compliance, reliability and stability. To maximize research and development activities in enterprises, tax incentives need to be transparent and easily accessible. In addition, tax incentives should be designed for longer time periods, efficient and have simple application rules in order to create a reliable and stable framework for enterprises. The basis of tax incentives for research and development shouldn't be frequently changed in order to ensure a higher corporate quality plan for research and development investment activities.

The European Commission has prescribed several principles for the main possibilities, features and relevant factors of tax incentives. Such principles define that tax incentives must (European Commission, COM (2006) 728 final):

1. Affect several enterprises with as high an increase of expenditures for research and development in the business sector as possible

2. Include all current expenditures and take into account certain types of capital expenditures for research and development

3. Focus on identifying the immediate additionality of tax incentives and their additionality with regard to behaviour

4. Consider criteria for evaluation and data from the creation phase

5. Examine whether tax incentives meet their respective objectives, their mechanism's management efficiency and wider influences on society.

Most tax incentives whose aim is to increase research and development are general. Such incentives include all types of enterprises, sectors or technologies. Half of the existing implemented tax incentives for research and development limit the general availability with the upper limit of the amount of the available tax burden. The upper limit presents a relative advantage for small and mediumsized enterprises. Advantage is achieved because their level of expenditures isn't covered within the upper limit. The dominant model of tax incentives for research and development aims at lowering the tax paid by enterprises for research costs. The usefulness of such incentives is proportional to the effective rates of corporate tax and can be in the form of relief. In achieving research and development objectives, fiscal policy has to ensure a general tax system that favours technological development. The level of tax incentives varies depending on the specific state conditions, existing industrial structure, level of corporate research and development, macroeconomic situation and tax environment. Public funds for basic research and development performed by universities are increasing and linked via additional stimulation for technology transfer to corporate research and development activities (Elschner et al. 2011). Each member state chooses a specific combination of tax incentives for research and development. Well-designed tax incentives can support business research and innovation in a simpler and more predictable way than grants (European Commission 2005).

\section{Tax Incentives for Research and Development}

The European economy has the task of achieving 3\% of GDP in research and development. By reaching 3\% of GDP by 2020, the European Union will ensure 3.7 million workplaces and an increase in its annual gross domestic product of nearly 800 billion Euros by 2025. Table 1 and Figure 1 present gross domestic expenditure on R\&D (GERD).

With its 27 member states, the European Union's average investment in research and development was $1.98 \%$ for the $2008-2010$ period. In the same 2008-2010 period, Finland invested $3.83 \%$ of its GDP on average, while Sweden invested $3.58 \%$. Cyprus invested the least $0.47 \%$ - of its GDP. Keeping in mind that the European Union's average result, with its 27 member states, is low, additional efforts and financial means have to be invested in order to reach the United States of America with its 2.79\% average in 2008 .

At the national level, the highest R\&D intensity in 2010 was recorded in Finland (3.87\%), Sweden (3.42\%) and 
Denmark (3.06\%). Some member states reported R\&D expenditure accounting for less than $1 \%$ of their GDP in 2010 (for example, Romania below 0.50\%). The regions with the lowest R\&D intensity were generally in Southern and Eastern Europe.

The most important factors for companies when deciding on research-development activities are: their approach to the market, the flexible disposition of researchers and their country's macroeconomic and political stability. A company usually chooses a country for its registered seat that has a regulated fiscal system and a policy to perform research and development. Research and development activities in a company result in new products that are the basis of sustainable growth and economy. The diversity of investment in research and development depends on the sector's type. Table 2 shows gross domestic expenditure on R\&D by sector.

Table 2 shows that the share of research and development in the business enterprise sector was equivalent to $1.23 \%$ of the EU-27 GDP in 2010, compared with $2.70 \%$ in Japan and $2.02 \%$ in the United States. Germany, with $0.41 \%$ of its GDP, and Slovenia, with $0.38 \%$ of its GDP, recorded the most expenditures in the government sector. Sweden and Denmark recorded the highest expenditures in the higher education sector, with $0.90 \%$ of their GDP. Given the structure of financing resources in the European Union, efforts are being made to increase the business enterprise sector's share, which would then dominate, comprising two thirds of investment in research and development. High research and development intensity is found to have a positive impact on firm efficiency, no matter whether low, medium or high-tech industries are considered (Kumbhakar et al. 2010).

\subsection{The Structure of Tax Incentives for Research and Development in The Republic Of Croatia}

Investment in research and development enables the Republic of Croatia to create a national research market as a part of both European and global research areas. Such a market is characterized by a high level of competition, mobility and research excellence. The country's economic development is slowed down due to a business enterprise sector that has been outdone with respect to research and development. The problems of transition and privatization have been present in Croatia for many years. Some of the key reasons behind the state of the business enterprise sector include (Bečić and Dabić 2008, p. 71):

1. Insufficient allocation for research and development in the private sector,

2. Unclear role of industrial policy in economic development strategies,

3. Weak relationship between the scientific sector and enterprises,

4. Existing industrial structure of economy,

5. Existing structure of funding source for research and development,

6. Low rate of investment in higher education,

7. Weak relationship between technology and science.

The nature of research and development is such that at the time when the cost of research and development occurs, it is impossible to measure with certainty the future economic benefits. It can only be assumed that long-term economic benefits are precisely the result of research and development costs. Small and start-up firms in research and development intensive industries face a higher cost of capital than their larger competitors and firms in other industries (Hall, 2002).

Upon accession to the European Union, government budget resources for research and development in the Republic of Croatia will become a constituent part of the European budget for research and development. Share of the government budget sources for research and development in the gross domestic product was $0.69 \%$ in 2009, while in 2010 it amounted to $0.71 \%$. In 2009 the most resources, $62.5 \%$, were given to higher education, followed by $34.4 \%$ for the government sector, while the amounts in 2010 were $\mathbf{7 0 . 0 8 \%}$ for higher education and $25.78 \%$ for the government sector.

Figure 2 presents funding resources for research and development in the Republic of Croatia in 2010 in thousands of Kunas (\%).

The main sources of resources for the business enterprise sector are own resources, comprising $68.7 \%$ of resources, and for the government sector state and local administration $80.1 \%$. This leads to a great discrepancy since most of the government sector's resource sources come from the state and local administration's budget, while business enterprise sector is self-financing.

Until 2003, Croatia offered tax relief for tax payers depending on place of business, amount of investment, as well as tax benefits in the form of tax payment deferrals. In order to encourage investment in research and development, that same year saw the introduction of 
relief for tax payers investing precisely in mentioned activities. The idea was to encourage research and development aimed at producing new products and procedures, the improvement of the existing and development of own know-how, and stimulation of the economic sector to invest more in research and development (Bratić and Urban, 2006). Tax incentives for research and development existed at the beginning of 2006 within the Value Added Tax Act. However, in May 2006, incentives were withdrawn and do not apply as of 1 January 2007. They have been since reintroduced and implemented in the Scientific Activity and Higher Education Act.

Tax incentives in Croatia can be grouped into six categories (Švaljek 2007, p. 71):

1. Tax incentives for business expenditures for research and development (business credits or deductions) a tax credit is a tax incentive in the form of the possibility of the reduction of tax liability for part of the expenditures for research and development, while tax deduction presents a possibility of decreasing the value added tax basis for the amount that exceeds investment in research and development;

2. Tax incentives for capital expenditures for research and development (one-time or accelerated depreciation);

3. Tax incentives for contracts with researchers (incentives in terms of the deduction of the income tax of employees or income tax when engaging experts);

4. Tax incentives for the transfer of technology (incentives that support the procurement of new technology or tax incentives for those who develop new technologies for the transfer of their knowhow);

5. Tax incentives for the cooperation of companies and research institutes, i.e. universities (tax incentives for collaborative projects);

6. Tax incentives for the creation of new firms (tax incentives for spin-off or spin-out).

The Republic of Croatia didn't have a tax credit or base deduction until 2003. That same year base deductions for research and development were introduced, as well as for employees' education and professional education. Deductions referred to all types of investments in research and development, such as fixed assets, current costs and wages. Legislative changes in 2005 introduced exemptions for tax payers performing only research and development activities. Table 3 presents government budget appropriations for research and development by socio-economic objectives in the Republic of Croatia.

According to the socio-economic objectives, most of the government budget appropriations for research and development in 2010 were invested for the objective of the general advancement of knowledge through research and development financed from general university funds (55.4\%) The general advancement of knowledge through research and development financed from other sources follows with $34.22 \%$, and the least amount of state budget resources, $0.13 \%$, was invested in defence. In 2011 most was invested in the objective of the general advancement of knowledge through research and development financed from general university funds (54.62\%) and least for the objective of the exploration and exploitation of space. The biggest increase of 58\% from 2010 was noted in transport, telecommunication and other infrastructure. Compared to 2010, the total state budget funds for research and development of the socio-economic objectives in the Republic of Croatia decreased by $4 \%$. The reduced resources are the result of the economic crisis, which did not bypass Croatia. Apart from the economic crisis, there are a number of structural problems that limit the further development of research and development in Croatia.

\section{The Choice between Tax Incentives and Direct Measures}

Tax incentives for research and development are a policy instrument because the state uses them to direct the development of a company or economy. In addition, they also encourage the business environment in attracting new investment. Every country meets the problem of the implementation of political instruments of the highest quality to stimulate enterprises to invest in the activities of research and development. To solve the problem, the state oriented political instruments towards the market. Such a possibility allows an enterprise to choose how to strive towards research and development. The state can stimulate investment in research and development through direct measures such as subventions, loans and grants and indirect measures such as tax incentives and tax credits. Tax incentives for the stimulation of the business sector to invest in research 


\begin{tabular}{|c|c|c|}
\hline & TAX INCENTIVES & DIRECT MEASURES \\
\hline ADVANTAGES & $\begin{array}{l}\text {-incentive to increase research and development } \\
\text { through every area of the company } \\
\text {-private sector's decision in choosing the most } \\
\text { productive manner of investment } \\
\text {-lower risk of government mistake in choosing the } \\
\text { wrong research-development project } \\
\text {-encouraging companies to report on income } \\
\text { more often } \\
\text {-lower administrative costs of planning, allocation } \\
\text { and management } \\
\text {-the easiest manner to increase business sector } \\
\text { participation in research and development }\end{array}$ & $\begin{array}{l}\text {-better budget control } \\
\text {-encouraging cooperation and technology transfers } \\
\text {-possibility of using specific technological and } \\
\text { scientific fields as an objective in overcoming circular } \\
\text { or sectoral slowing down } \\
\text {-contest between companies ensures that public } \\
\text { resources belong directly to the best research- } \\
\text { development projects } \\
\text {-best for high-risk projects } \\
\text {-adequate for achieving research-development } \\
\text { activities with the greatest disagreement between } \\
\text { social and private returns }\end{array}$ \\
\hline DISADVANTAGES & $\begin{array}{l}\text {-weak budget control } \\
\text {-higher risk of loss } \\
\text {-minor amendments in case of large companies } \\
\text {-company's risk that other activities will be } \\
\text { renamed research and development activities } \\
\text {-private companies will choose research- } \\
\text { development project with the highest return rate } \\
\text {-risk that globalization of research and } \\
\text { development might reduce overflow of local } \\
\text { research and development for society }\end{array}$ & $\begin{array}{l}\text {-high administration costs } \\
\text {-administratively not adjustable to large number of } \\
\text { applications } \\
\text {-companies won't commit to research-development } \\
\text { program that does not allow for public financing }\end{array}$ \\
\hline
\end{tabular}

Source: Adjusted by the author according to CEFAGUE-UE Working Paper 2011/4.

Table 4: Advantages and disadvantages of tax incentives and direct measures

and development are the most important instruments in the fiscal policies of European Union member states.

The European Commission encourages member states to equally use both types of measures. Each of these types has some advantages, as well as disadvantages. Table 4 gives an overview of the advantages and disadvantages of tax incentives and direct measures.

Source: adjusted by the author according to CEFAGUE-UE Working Paper 2011/4.

Each measure, whether direct or indirect, depends on the political objectives of the state. According to the strategic level of the state, tax incentives are more appropriate for international investment in research and development. If the objective of research and development policy is to encourage a large number of enterprises and increase the amount of the business sector's investment in research and development, tax incentives should be applied. Direct measures are more often used as state support for research and development. Direct R\&D subsidies or government spending on basic research activities should not be expected to displace private real R\&D investment (David, Hall, and Toole 2000). Investment in research and development decreases inequality among the European Union member states, as well as among the countries outside the EU's borders. The tax treatment of R\&D is becoming more lenient and it is likely that countries will increasingly turn to the tax system and away from direct grants (Hall and Van Reenen 2000, p. 466). Investors will also need to be able to rely on a certain stability of the tax incentives granted, before engaging in a major investment (Klemm 2010, p. 323).

\section{Conclusion}

The activity of research and development is an important factor when it comes to the increase of productivity, economic efficiency and achievement of long-term economic growth. Each country has a right to independently choose whether to finance incentives for research and development directly or indirectly through tax incentives.

The introduction of tax incentives for research and development presents a foundation for an increase in national and international investments. The types of tax incentives for research and development also depend on the type of fiscal system and certain political objectives. The introduction of tax incentives for research and development is an attempt to support certain activities. They enable the reduction of imperfections in certain 
sections of the fiscal structure and encourage the private sector to participate in economic and social programs. For countries, such as Croatia, that face the problem of transition and privatization and are about to join the European Union, it is highly important to invest in research and development. It enables them to create a national research market characterized by high levels of competitiveness and research excellence. In comparison to certain members of the European Union, Croatia still recognizes the trend of lagging behind in investment in research and development. On one hand, this is the consequence of the insufficient investment of the business sector in research and development and the unclear role of industrial policy in economic growth strategies, and, on the other, of the weak connection between the scientific sector and enterprises and the low rate of investment in higher education.

The European Union faces the problem of the dispersion of the actual effects for research and development. Most scientific researchers are conducted on the national level, mostly within national and regional research programs financed by the European Union. Compared to the United States of America, it is thought that the European Union does not invest sufficient resources in research and development in order to encourage economic growth. Therefore, in order to become competitive on a global level, the European Union has set the strengthening of the scientific and technological foundations of industry based upon increasing investment in research and development to $3 \%$ of GDP as one of its fundamental objectives, in line with the Horizon 2020 strategy. Joint investment of the European Union and Croatia in the field of research and development is useful in order to accumulate knowledge that can significantly increase factor production, innovative processes and the effects of knowledge overflow to all economic entities, thus influencing total economic growth and employment. The Republic of Croatia needs to invest additional efforts in order to reach certain members of the European Union in the area of tax incentives for research and development. $[$.

\section{References}

Batty, J. 1976. Accounting for research and development. London: Business Book.

Bečić, E. and Dabić, M. 2008. Analysis of Croatian business sector investment in R\&D. Sociological Review, 39 (1-2): 69-84.
Bratić, V. and Urban, I. 2006. Tax expenditures in Croatia. Financial Theory and Practice, 30 (2): 129-195.

Carvalho, A. 2011. Why are tax incentives increasingly used to promote private R\&D?. CEFAGE-UE Working paper 4, Cefage: Portugal.

Central Bureau of Statistics of the Republic of Croatia. 2010. Note 8.2.1..

-_- 2012. Note 8.2.3.

David, P.A., Hall, B.H. and Toole, A.A. 2000. Is public R\&D a complement or substitute for private R\&D? A review of econometric evidence. Research Policy 29: 497-529.

Elschner, C. et.al. 2011. What the design of an R\&D tax incentive tells about its effectiveness: a simulation of R\&D tax incentives in the European Union. Journal of Technology Transfer 36: 233-256.

European Commission. 2006. Towards a more effective use of tax incentives in favour of R\&D. Communication 728 final. Bruxelles.

_-_ 2005. More research and innovation: A common approach. Communication 488 final. Belgium.

Eurostat. 2011. Research and development: annual statistics. Bruxelles.

Hall, B. and Van Reenen, J. 2000. How effective are fiscal incentives for R\&D? A review of the evidence. Research Policy 29: 449-469.

Hall, B. 2002. The financing of research and development. Oxford review of economic policy 18 (1): 35-51.

Hinloopen, J. 2001. Subsidizing R\&D Cooperatives. De Economist 149 (3): 313-345.

Hutschenreiter, G. 2002. Tax incentives for research and development. Austrian Economic Quarterly 2: 74-85.

Kesner-Škreb, M. 2001. Tax incentives. Financial Theory and Practice 25 (4): 633-636.

Klemm, A. 2010. Causes, benefits and risks of business tax incentives. International Tax and Public Finance. 17 (3): 315-336.

Klemm, A. and Van Parys, S. 2012. Empirical evidence on the effects of tax incentives. International Tax and Public Finance. 19 (3): 393-423.

Kumbhakar et.al. 2010. Corporate R\&D and firm efficiency: evidence from Europe's top R\&D investors. IPTS Working Paper on corporate R\&D and Innovation 11. Joint Research Centre: Spain.

Moncada-Paterno-Castello, P. et al. 2010. Does Europe perform too little corporate R\&D? A comparison of EU and nonEU corporate R\&D performance. Research Policy 39: 523-536.

OECD. 2002. Frascati Manual: proposed standards practice for surveys on research and experimental development. Paris.

Sanchez-Gonzales, G. and Herrera L. 2010. The influence of $R \& D$ cooperation on innovatory effort. Innovation: Management, policy and practice 12 (3): 337-354. 
Švaljek, S. 2007. Private Equity and Venture Capital Industry in Croatia: Tax and Legal Environment. Economic Trends and Economic Policy, 17 (113): 53-84.
Tassey, G. 2007. Tax incentives for innovation: time to restructure the R\&E tax credit. Journal of Technology Transfer 32: 605-615.

\section{Appendix: Tables and Figures}

\begin{tabular}{|c|c|c|c|c|}
\hline & 2008 & 2009 & 2010 & AVERAGE \\
\hline Belgium & 1,97 & 2,03 & 1,99 & 2,00 \\
\hline Bulgaria & 0,47 & 0,53 & 0,60 & 0,53 \\
\hline Czech Republic & 1,41 & 1,48 & 1,56 & 1,48 \\
\hline Denmark & 2,85 & 3,06 & 3,06 & 2,99 \\
\hline Germany & 2,69 & 2,82 & 2,82 & 2,78 \\
\hline Estonia & 1,28 & 1,43 & 1,62 & 1,44 \\
\hline Ireland & 1,45 & 1,74 & 1,79 & 1,66 \\
\hline Greece & - & - & - & - \\
\hline Spain & 1,35 & 1,39 & 1,39 & 1,38 \\
\hline France & 2,12 & 2,26 & 2,26 & 2,21 \\
\hline Italy & 1,21 & 1,26 & 1,26 & 1,24 \\
\hline Cyprus & 0,43 & 0,49 & 0,50 & 0,47 \\
\hline Latvia & 0,62 & 0,46 & 0,60 & 0,56 \\
\hline Lithuania & 0,79 & 0,83 & 0,79 & 0,80 \\
\hline Luxembourg & 1,57 & 1,66 & 1,63 & 1,62 \\
\hline Hungary & 1,00 & 1,17 & 1,16 & 1,11 \\
\hline Malta & 0,56 & 0,54 & 0,63 & 0,58 \\
\hline Netherlands & 1,77 & 1,82 & 1,83 & 1,81 \\
\hline Austria & 2,67 & 2,72 & 2,76 & 2,72 \\
\hline Poland & 0,60 & 0,68 & 0,74 & 0,67 \\
\hline Portugal & 1,50 & 1,64 & 1,59 & 1,58 \\
\hline Romania & 0,58 & 0,47 & 0,47 & 0,51 \\
\hline Slovenia & 1,65 & 1,86 & 2,11 & 1,87 \\
\hline Slovakia & 0,47 & 0,48 & 0,63 & 0,53 \\
\hline Finland & 3,70 & 3,92 & 3,87 & 3,83 \\
\hline Sweden & 3,70 & 3,61 & 3,42 & 3,58 \\
\hline United Kingdom & 1,79 & 1,86 & 1,77 & 1,81 \\
\hline Iceland & 2,64 & 3,11 & - & 2,88 \\
\hline Norway & 1,61 & 1,80 & 1,71 & 1,71 \\
\hline Switzerland & 2,99 & - & - & 2,99 \\
\hline Croatia & 0,89 & 0,83 & 0,73 & 0,82 \\
\hline Turkey & 0,73 & 0,85 & - & 0,79 \\
\hline EU- 27 & 1,92 & 2,01 & 2,00 & 1,98 \\
\hline
\end{tabular}

Source: Eurostat. 2011. Research and development: annual statistics. Bruxelles. Table 1: Gross domestic expenditure on R\&D (GERD) (\% share of GDP) 


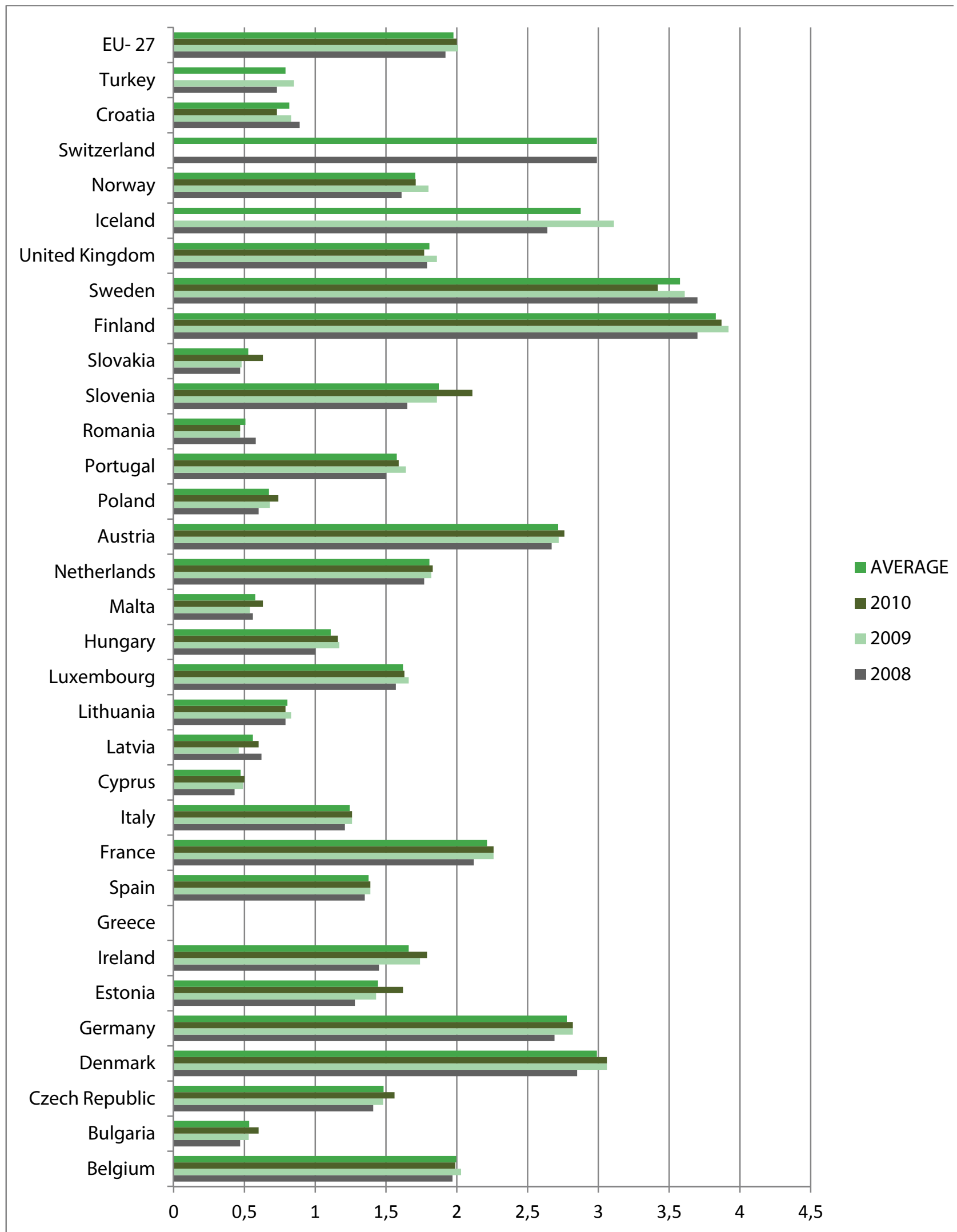

Figure 1: Gross domestic expenditure on R\&D (GERD) (\% share of GDP) 


\begin{tabular}{|c|c|c|c|c|c|c|}
\hline & \multicolumn{2}{|c|}{ Business enterprise sector } & \multicolumn{2}{|c|}{$\begin{array}{c}\text { Government } \\
\text { sector }\end{array}$} & \multicolumn{2}{|c|}{$\begin{array}{l}\text { Higher education } \\
\text { sector }\end{array}$} \\
\hline & 2005 & 2010 & 2005 & 2010 & 2005 & 2010 \\
\hline EU-27 & 1,15 & 1,23 & 0,25 & 0,27 & 0,41 & 0,49 \\
\hline Belgium & 1,24 & 1,32 & 0,15 & 0,19 & 0,41 & 0,46 \\
\hline Bulgaria & 0,10 & 0,30 & 0,31 & 0,22 & 0,05 & 0,07 \\
\hline Czech Republic & 0,86 & 0,97 & 0,27 & 0,30 & 0,22 & 0,28 \\
\hline Denmark & 1,68 & 2,08 & 0,16 & 0,06 & 0,60 & 0,90 \\
\hline Germany & 1,74 & 1,90 & 0,35 & 0,41 & 0,41 & 0,51 \\
\hline Estonia & 0,42 & 0,81 & 0,11 & 0,17 & 0,39 & 0,62 \\
\hline Ireland & 0,81 & 1,22 & 0,09 & 0,06 & 0,34 & 0,51 \\
\hline Greece & 0,19 & - & 0,12 & - & 0,28 & - \\
\hline Spain & 0,60 & 0,71 & 0,19 & 0,28 & 0,33 & 0,39 \\
\hline France & 1,31 & 1,38 & 0,37 & 0,37 & 0,40 & 0,48 \\
\hline Italy & 0,55 & 0,67 & 0,19 & 0,18 & 0,33 & 0,36 \\
\hline Cyprus & 0,09 & 0,09 & 0,13 & 0,10 & 0,16 & 0,25 \\
\hline Latvia & 0,23 & 0,22 & 0,11 & 0,14 & 0,23 & 0,24 \\
\hline Lithuania & 0,15 & 0,23 & 0,19 & 0,14 & 0,41 & 0,42 \\
\hline Luxembourg & 1,35 & 1,16 & 0,19 & 0,29 & 0,02 & 0,19 \\
\hline Hungary & 0,41 & 0,69 & 0,26 & 0,21 & 0,24 & 0,23 \\
\hline Malta & 0,38 & 0,37 & 0,03 & 0,02 & 0,16 & 0,23 \\
\hline Netherlands & 1,01 & 0,87 & 0,24 & 0,22 & 0,66 & 0,75 \\
\hline Austria & 1,72 & 1,88 & 0,13 & 0,15 & 0,61 & 0,72 \\
\hline Poland & 0,18 & 0,20 & 0,21 & 0,26 & 0,18 & 0,27 \\
\hline Portugal & 0,30 & 0,72 & 0,11 & 0,11 & 0,28 & 0,59 \\
\hline Romania & 0,20 & 0,18 & 0,14 & 0,17 & 0,06 & 0,12 \\
\hline Slovenia & 0,85 & 1,43 & 0,35 & 0,38 & 0,24 & 0,29 \\
\hline Slovakia & 0,25 & 0,27 & 0,15 & 0,19 & 0,10 & 0,17 \\
\hline Finland & 2,46 & 2,69 & 0,33 & 0,36 & 0,66 & 0,79 \\
\hline Sweden & 2,59 & 2,35 & 0,18 & 0,17 & 0,78 & 0,90 \\
\hline United Kingdom & 1,06 & 1,08 & 0,18 & 0,17 & 0,44 & 0,48 \\
\hline Iceland & 1,43 & - & 0,65 & - & 0,61 & - \\
\hline Norway & 0,81 & 0,88 & 0,24 & 0,28 & 0,47 & 0,55 \\
\hline Switzerland & - & - & - & - & - & - \\
\hline Croatia & 0,36 & 0,32 & 0,21 & 0,20 & 0,30 & 0,21 \\
\hline Turkey & 0,20 & - & 0,07 & - & 0,32 & - \\
\hline Japan & 2,54 & 2,70 & 0,28 & 0,29 & 0,45 & 0,40 \\
\hline United States & 1,79 & 2,02 & 0,31 & 0,30 & 0,36 & 0,36 \\
\hline
\end{tabular}

Source: Eurostat. 2011. Research and development: annual statistics. Bruxelles.

Table 2: Gross domestic expenditure on R\&D by sector (\% share of GDP) 


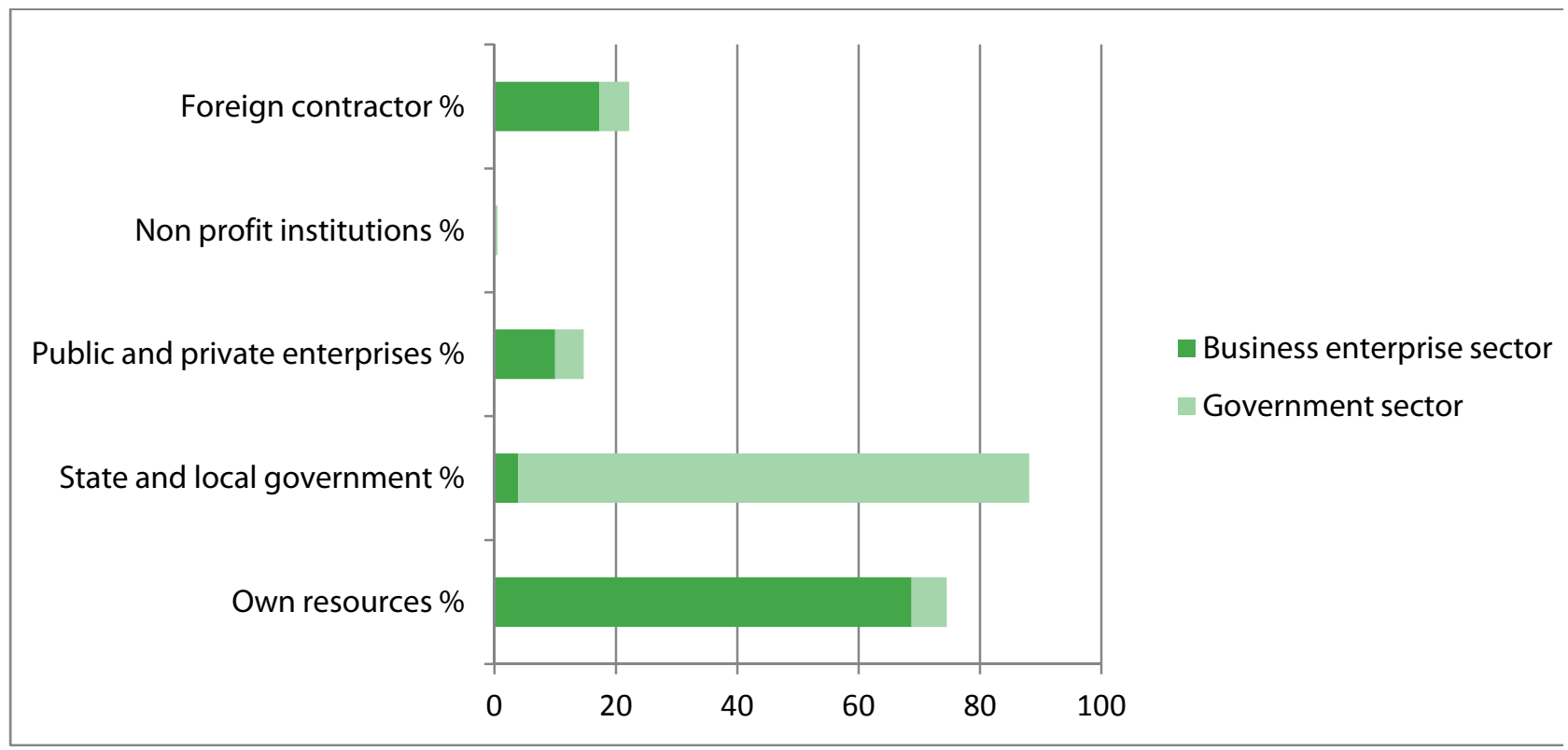

Source: Central Bureau of Statistics of the Republic of Croatia. 2010. Note 8.2.1.

Figure 2: Funding resources for the research and development in the Republic of Croatia in 2010 in thousands of Kunas (\%)

\begin{tabular}{|c|c|c|}
\hline & \multicolumn{2}{|c|}{$\begin{array}{l}\text { Thousand } \\
\text { Kunas }\end{array}$} \\
\hline & 2010 & 2011 \\
\hline Exploration and exploitation of the Earth & 24524 & 25467 \\
\hline Environment & 10773 & 12754 \\
\hline Exploration and exploitation of space & 3605 & 1117 \\
\hline Transport, telecommunication and other infrastructures & 33406 & 52930 \\
\hline Energy & 8397 & 5924 \\
\hline Industrial production and technology & 39929 & 25177 \\
\hline Health & 37683 & 37156 \\
\hline Agriculture & 18337 & 20813 \\
\hline Education & 9606 & 6309 \\
\hline Culture, recreation, religion and mass media & 29436 & 24772 \\
\hline Political and social system, structures and processes & 25775 & 33264 \\
\hline $\begin{array}{l}\text { General advancement of knowledge: R\&D financed from general university } \\
\text { funds }\end{array}$ & 1311855 & 1245208 \\
\hline $\begin{array}{l}\text { General advancement of knowledge: R\&D financed from other sources than } \\
\text { general university funds }\end{array}$ & 809753 & 786563 \\
\hline Defence & 2988 & 2487 \\
\hline TOTAL & 2366067 & 2279941 \\
\hline
\end{tabular}

Source: Central Bureau of Statistics of the Republic of Croatia. 2012. Note 8.2.3.

Table 3: Government budget appropriations for research and development by socio-economic objectives in 2010-2011 in Croatia 